\begin{tabular}{|c|c|}
\hline Title & $\begin{array}{l}\text { Immobilization of selenium by Mg-bearing minerals and its implications for selenium removal from contaminated water } \\
\text { and wastewater }\end{array}$ \\
\hline Author(s) & O piso, Einstine M.; Sato, T sutomu; Y oneda, T etsuro \\
\hline Citation & $\begin{array}{l}\text { A pplied clay science, 123, 121-128 } \\
\text { https://doi.org/10.1016j.clay.2016.01.023 }\end{array}$ \\
\hline Issue Date & $2016-04$ \\
\hline Doc URL & http:/hdl.handle.net/2115/68643 \\
\hline Rights & $\begin{array}{l}\text { (0) 2016, Elsevier. This manuscript version is made available under the CC-BY-NC-ND } 4.0 \text { license } \\
\text { http://creativecommons.org/icenses/fy-nc-nd/4.0/ }\end{array}$ \\
\hline Rights(URL) & https://creativecommons.org/icenses/by-nc-nd/4.0/ \\
\hline Type & article (author version) \\
\hline File Information & Opiso_selenate paper without highlights.pdf \\
\hline
\end{tabular}

Instructions for use 


\title{
Immobilization of selenium by Mg-bearing minerals and its implications for selenium removal from contaminated water and wastewater
}

Einstine M. Opiso ${ }^{\mathrm{a}^{*}}$, Tsutomu Sato ${ }^{\mathrm{b}}$, Tetsuro Yoneda ${ }^{\mathrm{b}}$

${ }^{\mathrm{a}}$ Geo-environmental Engineering Group, Civil Engineering Department, College of Engineering, Central Mindanao University 8710 Philippines

Laboratory of Environmental Geology, Graduate School of Engineering, Hokkaido University, Sapporo, Japan

*Corresponding author:

Einstine M. Opiso

Geo-environmental Engineering Group

Civil Engineering Department

College of Engineering

Central Mindanao 8710 Philippines

\begin{abstract}
This study examines the possible immobilization of Se(VI) by Mg-bearing hydrotalcite and serpentine-like minerals. Selenate immobilization was carried out via adsorption and coprecipitation reactions under alkaline conditions. The effects of $\mathrm{Mg} / \mathrm{Al}$ ratios, temperature and initial Se concentration on the adsorption and/or coprecipitation of $\mathrm{Se}^{6+}$ onto these $\mathrm{Mg}$ bearing minerals were examined. The sorption mechanism of Se(VI) was examined by XAFS analysis to give account of its local coordination environment. The results showed that Se(VI) sorption behavior by hydrotalcite and serpentine-like minerals was mainly influenced by their $\mathrm{Mg} / \mathrm{Al}$ ratio. Higher removal efficiency of Se(VI) (> 60 and 90\% at 100 and $10 \mathrm{ppm}$ initial Se concentration) was observed during coprecipitation onto hydrotalcite and serpentine-like phases with $\mathrm{Mg} / \mathrm{Al}$ ratios of 2 and 1.25, respectively. The formation of Mg-bearing minerals was enhanced at higher temperature (at $75^{\circ} \mathrm{C}$ ) but the effect of temperature in Se(VI) immobilization was very minimal. Selenate was mainly retained via outer-sphere complexation but an irreversible fraction of sorbed selenate (about 20\%) was observed in these mineral phases. In overall, this study has several important implications in the possible application of hydrotalcite and aluminian serpentine in Se(VI) immobilization.
\end{abstract}

Keywords: Hydrotalcite, aluminian serpentine, selenate treatment, alkaline condition 


\section{Introduction}

Selenium (Se) is an essential micronutrient but toxic at high concentrations, so it is one of the most strictly regulated trace inorganic elements in the environment (Santos et al., 2015). The USEPA set 5 $\mu \mathrm{g} / \mathrm{L}$ as the regulatory limit in surface water because this concentration is the maximum exposure limit for aquatic communities without any significant effects (USEPA, 2014). In humans, Se at high concentrations increase the risks of developing breast, colorectal and kidney cancers, melanoma and lymphoid neoplasms, Parkinson’s disease and amyotropic lateral sclerosis (ALS) (Taylor et al., 2009). The provisional drinking water limit recommended by WHO and adopted by most of the developed countries is $10 \mu \mathrm{g} / \mathrm{L}$. Prohibitively high amounts of Se can be introduced into the environment through various natural and anthropogenic sources such as localized geological anomalies (Sigrist et al., 2012), mine drainage (Sasaki et al., 2008) as well as from wastes materials from coal power plants, oil refineries and metal extraction industries (Cornelis et al., 2008). More recently, large quantities of coal processing wastes (Chugh and Behum, 2014) and rocks from tunnel excavation for road and railway construction (Tabelin et al., 2014; Tamoto et al., 2015) had been reported to leach out substantial amounts of Se that necessitated treatment.

Dissolved Se (i.e., Se in surface and ground waters including waste waters) predominantly exists as either Se(IV) or Se(VI) species depending on the $\mathrm{pH}$ and redox conditions (Goldberg, 2012). Previous studies have shown that both of these oxidation states of Se form oxyanions that undergo $\mathrm{pH}$ dependent protonatation-deprotonation reactions. Selenate which has two oxyanions $\left(\mathrm{HSeO}_{4}^{-}\right.$and $\mathrm{SeO}_{4}{ }^{2-}$ ), is the dominant species in natural oxic waters and wastewaters but is less toxic compared to Se(IV) (Santos et al., 2015). In comparison, Se(IV) forms three oxyanions $\left(\mathrm{H}_{2} \mathrm{SeO}_{3}, \mathrm{HSeO}_{3}{ }^{-}\right.$and $\mathrm{SeO}_{3}{ }^{2-}$ ) and the dominant species under reducing conditions (Das et al., 2013). However, it is not uncommon for these two species to co-exist in groundwater because the oxidation of Se(IV) to Se(VI) by $\mathrm{O}_{2}$ is very slow (Masscheleyn et al., 1990). Among these two, Se(IV) is less mobile because it easily adsorbs onto positively charged metallic oxyhydroxides like ferrihydrite as well as onto negatively charged clay minerals like kaolinite (Das et al., 2013). In contrast, Se(VI) is very mobile in 
the environment because it barely adsorbs onto both negatively charged and positively charged mineral surfaces even though it also exist as a negatively charged oxyanion (Goldberg, 2012). Because of this, removal of Se(VI) in contaminated waters by chemical approaches is very difficult and require its reduction first to Se(IV) that is followed by its adsorption onto various minerals surfaces such as aluminum, iron, manganese, and titanium oxides and clay minerals (Goldberg, 2013). Because of the strong stability of Se(VI), its reduction to Se(IV) is kinetically sluggish and requires the use of strong reducing agents that are difficult to handle during treatment (Santos et al., 2015). Thus, alternative methods that do not involve reducing agents in the removal of Se(VI) from contaminated water should be explored.

One possible alternative approach is to use hydrotalcite and aluminian serpentine as adsorbents under alkaline conditions. Removal of Se(VI) by simply raising the $\mathrm{pH}$ is easier and more economical than the use of strong reducing agents. Hydrotalcite has a general formula of $\left(\mathrm{M}^{2+}{ }_{1-\mathrm{x}} \mathrm{M}^{3+}{ }_{\mathrm{x}}\left(\mathrm{A}^{\mathrm{n}-}\right)_{\mathrm{x} / \mathrm{n}}(\mathrm{OH})_{2}\right.$. $\mathrm{mH}_{2} \mathrm{O}$ ), where $\mathrm{M}^{2+}$ and $\mathrm{M}^{3+}$ are divalent and trivalent cations, respectively, $\mathrm{x}$ is equal to the ratio $\mathrm{M}^{2+} /\left(\mathrm{M}^{2+}+\mathrm{M}^{3+}\right)$, and $\mathrm{A}^{\mathrm{n}-}$ is the interlayer anion with negative charge $\mathrm{n}$. while aluminian serpentine has a chemical formula of $\left(\mathrm{Mg}_{3-\mathrm{x}} \mathrm{Al}_{\mathrm{x}}\right)\left(\mathrm{Si}_{2-\mathrm{x}} \mathrm{Al}_{\mathrm{x}}\right) \mathrm{O}_{5}(\mathrm{OH})_{4}$ where $\mathrm{x}$ could increase from 0.25 to 1.0 (De La Calle et al., 2003). These mineral phases can be found exceptionally in natural environment such as the hyperalkaline springs in Oman (Anraku et al., 2008), hydrotalcite deposit in Snarum, Norway (De La Calle et al., 2003), ternary debris flows in Northern Southland, New Zealand (Craw et al., 1987) and Khabarovsk region in Russia (Moroz et al., 2001). The natural association of hydrotalcite and aluminian serpentine could be related to their compositional $\mathrm{Mg} / \mathrm{Al}$ ratio which is close to 3.0 (De La Calle et al., 2003). Moreover, these minerals which were synthesized in Mg-Si-Al systems in previous studies showed surprisingly strong adsorption capacities for fluoride (Liu et al., 2012) and arsenate (Opiso et al., 2010; Opiso et al., 2012).

The main goal of this research is to evaluate the possibility of developing direct removal techniques of $\mathrm{Se}(\mathrm{VI})$ from wastewater using hydrotalcite and aluminian serpentine via adsorption and coprecipitation reactions under alkaline conditions. Specifically, the effects of temperature, $\mathrm{Mg} / \mathrm{Al}$ ratio 
and initial Se concentration on the adsorption and/or co-precipitation of Se(VI) onto these Mg-bearing minerals were examined. Moreover, X-ray absorption fine structure analysis (XAFS) was carried out in order to give insights into the mechanisms involved in the adsorption and/or incorporation of $\mathrm{Se}(\mathrm{VI})$.

\section{Materials and Methods}

\subsection{Synthesis of Mg-bearing minerals}

The Mg-bearing minerals were synthesized after the procedure developed by Opiso et al., (2010) by mixing stock solutions of $0.03 \mathrm{M} \mathrm{Na}_{2} \mathrm{SiO}_{3}$ with $0.09 \mathrm{M} \mathrm{NaNO}_{3}, 0.03 \mathrm{M} \mathrm{Mg}\left(\mathrm{NO}_{3}\right)_{2} \cdot 6 \mathrm{H} 2 \mathrm{O}$ with $0.03 \mathrm{M}$ $\mathrm{NaNO}_{3}$ and $0.03 \mathrm{M} \mathrm{Al}\left(\mathrm{NO}_{3}\right)_{3} \cdot 9 \mathrm{H}_{2} \mathrm{O}$ at various temperature conditions of 25,50 and $75^{\circ} \mathrm{C}$. The $\mathrm{Mg} / \mathrm{Si} / \mathrm{Al}$ molar ratios were varied from 9:1:0 to 3:1:6 with a constant Si molar ratio equal to 1 . The pH was adjusted to $11 \pm 0.5$ by adding $5 \mathrm{M}$ of $\mathrm{NaOH}$ solution and the solution were then shaken for 7 days. The precipitates were collected by centrifugation and was freeze-dried prior to any analysis. The mineralogy of the precipitates was examined by X-ray Diffraction (RINT-2100V/PCdiffractometer, Rigaku, Japan) with Ni-filtered $\mathrm{Cu}-\mathrm{K} \alpha$ radiation at $30 \mathrm{kV}$ and $20 \mathrm{~mA}$. The nomenclature of the samples were also patterned after their corresponding $\mathrm{Mg} / \mathrm{Si} / \mathrm{Al}$ molar ratios which varied from MSA 910 (Mg, Si and Al molar ratio of 9:1:0) to MSA 316 (Mg, Si and Al molar ratio of 3:1:6).

\subsection{Selenate adsorption and coprecipitation reactions}

For coprecipitation experiments, appropriate amounts of $\mathrm{Na}_{2} \mathrm{SeO}_{4}$ solutions was instantaneously added during synthesis of Mg-bearing minerals to obtain an initial Se(VI) concentration of $100 \mathrm{ppm}$. The solutions were shaken for 7 days prior to collection and analysis. In the case of adsorption experiments, $\mathrm{Se}(\mathrm{VI})$ was added only into the solution after synthesis (7 days) and was further shaken for additional 7 days. Similar experiments were also conducted at lower Se(VI) concentration of 10 ppm (at $25^{\circ} \mathrm{C}$ only) to examine the effect of initial Se concentrations. The remaining $\mathrm{Se}(\mathrm{VI})$ 
concentration was measured using Inductively Coupled Plasma-Atomic Emission Spectroscopy (ICPAES) (ICPE-9000 Shimadsu, Japan) while the solid samples were analyzed by X-ray Diffraction. The amount of sorbed $\mathrm{Se}(\mathrm{VI})$ was calculated based on the amount of $\mathrm{Se}(\mathrm{VI})$ removed from the solution and the amount of dried precipitates.

\subsection{Stability test of selenate using phosphate anion extractant}

The stability of sorbed Se(VI) was examined following the desorption procedure employed by Opiso et al., (2010). Twenty (20) $\mathrm{mg}$ of each mineral sample was added to $40 \mathrm{~mL}$ of $0.1 \mathrm{M} \mathrm{Na}_{2} \mathrm{HPO}_{4}$ solution. The extraction was carried by shaking the solution for 7 days prior to measurement of Se concentration using ICP-AES. The desorption efficiency was calculated based on the amount of Se(VI) released into the solution per grams solid precipitates which was collected after adsorption and coprecipitation experiments. Also, the difference between the desorption efficiency of Se(VI) after adsorption and coprecipitation experiments was the basis in deriving the irreversibly sorbed Se(VI) in this study. Hence, irreversible fraction exists if the desorption efficiency of Se(VI) from adsorption reactions is higher compared to coprecipitation.

\subsection{XAFS analysis}

XAFS analyses were conducted on selected samples with notable irreversible fraction of Se to determine Se(VI) retention mechanism unto Mg-bearing minerals. The selenium K-edge XAFS spectra were measured at BL9A, Photon Factory, KEK, Japan in which the synchrotron radiation from 2.5 GeV storage ring was monochromatized with Si (111) double crystal monochromator. The scanning was carried out from 12600 to $13000 \mathrm{eV}$ in order to obtain the Se K-edge XAFS spectra. Moreover, the EXAFS data were extracted from the raw data by following the procedure of Charnock et al., (2007). 


\section{Results and Discussions}

156

\subsection{Mineralogy of synthesized Mg-bearing minerals}

158

159

Figure 1 shows the mineralogy of pure synthesized hydrotalcite and serpentine-like minerals formed at 25 and $75^{\circ} \mathrm{C}$ as influenced by their $\mathrm{Mg} / \mathrm{Al}$ ratio (data of $50^{\circ} \mathrm{C}$ not shown). The compund with measured basal spacing of more than $7.51 \AA$ with $\mathrm{Mg} / \mathrm{Al}$ molar ratio greater than 2 (MSA 811 to MSA 613) can be classified as hydrotalcite while the generated phases with $\mathrm{Mg} / \mathrm{Al}$ molar ratio less than 2 and a basal spacing of less than $7.50 \AA$ can be classified as serpentine (MSA 514 to MSA 316) (Opiso et al., 2012). The formation of serpentine-like phases could be explained by the formation of polysilicate where $\mathrm{SiO}_{4}$ units condense with the same orientation (Albertazzi et al., 2007; Baskaran et al., 2013). The attachment of these silicate layers onto the brucite-like sheet coupled with the decreasing basal spacing as more $\mathrm{Mg}$ is replaced by $\mathrm{Al}$ possibly occurred during their formation (Mizutani et al., 1990; Depege et al., 1996; Opiso et al., 2012).

Moreover, the presence of silicate in the interlayer leads to lower crystallinity not only in the basal direction but also within layers similar to the previous results of Mg-Al hydrotalcite intercalated with silicate anion (Albertazzi et al., 2007; Baskaran et al., 2013). However, the generated mineral phases showed increasing crystallinity at $75^{\circ} \mathrm{C}$ in which sharper peaks of hydrotalcite can be clrearly observed compared to generated phases at $25^{\circ} \mathrm{C}$. At higher $\mathrm{Al}$ concentration (MSA 316), bayerite and gibbsite were also formed in addition to serpentine at $25^{\circ} \mathrm{C}$ and $75^{\circ} \mathrm{C}$, respectively. On the other hand, brucite was generated in the absence of $\mathrm{Al}$ (MSA 910) and at higher temperature of $75^{\circ} \mathrm{C}$ with higher Mg concentration (MSA 811). 


\subsection{Selenate adsorption reactions}

Mineralogy of the synthesized phases

185

\section{Selenate adsorption behavior}

Figure 4 presents the removal efficiency of $\mathrm{Se}(\mathrm{VI})$ after adsorption experiments at different temperature conditions (A) and initial Se concentration (B). Regardless of initial Se concentration, the removal efficiency of $\mathrm{Se}(\mathrm{VI})$ increased from MSA 811 to 613 (Mg/Al ratio from 8 to 2) and decreased thereafter from MSA 514 to MSA 316 (Mg/Al ratio from 1.25 to 0.5). The optimum removal efficiency of more than 50\% (at $100 \mathrm{ppm}$ initial Se concetration) and 80\% (at $10 \mathrm{ppm}$ initial Se concetration) which was observed in MSA 613 and 514 samples corresponds to hydrotalcite and serpentine phases with $\mathrm{Mg} / \mathrm{Al}$ ratio of 2.0 and 1.25, respectively. This high removal efficiency of 
$\mathrm{Se}(\mathrm{VI})$ by Mg-bearing minerals is very significant because of the absence of any reported findings on various mineral surfaces that can directly remove Se(VI) from aqeuous solutions at alkaline conditions. The presence of silicate anion in the interlayer of $\mathrm{Mg}-\mathrm{Al}$ hydrotalcite with $\mathrm{Mg} / \mathrm{Al}$ ratio close to 3.0 tends to have higher specific surface area and a more homogeneous pore size distribution (Albertazzi et al., 2007; Baskaran et al., 2013). The anion-exchange capacity (AEC) of Mg-bearing minerals also increases with decreasing $\mathrm{Mg} / \mathrm{Al}$ ratio (You et al., 2001) as more $\mathrm{Al}$ substitutes for $\mathrm{Mg}$ in the brucite-like sheets (De La Calle et al., 2003). However, the presence of some silicate species adsorbed on the particle surface cannot be ruled out as reported by Albertazzi et al., (2007) and this could significantly influence Se(VI) adsorption. In addition, the effects of temperature on Se(VI) adsorption by hydrotalcite and serpentine-like minerals showed no significant trend and needs further investigation.

\subsection{Selenate coprecipitation reactions}

\section{Mineralogy of the synthesized phases}

Table 2 shows the $\mathrm{Mg} / \mathrm{Al}$ ratio, solid mineralogy of synthesized mineral phases and sorbed amount of selenate by the mineral phases after coprecipitation experiments at different temperature conditions. Similar findings were also observed in the differentiation of Mg-bearing phases as the $\mathrm{Mg} / \mathrm{Al}$ ratio varies. The generated phases varied from hydrotalcite (MSA 811 to 613 systems) to serpentine (MSA 514 to 316 systems) as shown in Figure 5. The mineral phases also showed increasing crystallinity with increasing temperature as sharper peaks of hydrotalcite and serpentine-like minerals phases can be observed at $50^{\circ} \mathrm{C}$ (data not shown) and $75^{\circ} \mathrm{C}$. The presence of additional peak in MSA 514 samples was also observed at ambient temperature as well as in MSA 415 samples at higher initial Se concentration. Hence, the presence of Se(VI) seemed to affect the differentiation of hydrotalcite and serpentine phases in MSA 514 and MSA 415 samples. The additional peak also disappeared at $50^{\circ} \mathrm{C}$ and $75^{\circ} \mathrm{C}$, and less evident at much lower Se concentration. Figure 6 shows the XRD patterns of Mgbearing minerals formed in the presence of lower Se(VI) concentration. 
Selenate coprecipitation behavior

239

The removal efficiency of Se(VI) during coprecipitation experiments showed similar trend with adsorption experiments in relation to the effect of $\mathrm{Mg} / \mathrm{Al}$ ratio. Figure 7 presents the removal efficiency of Se(VI) during coprecipitation with Mg-bearing minerals at different temperature conditions (A) and initial Se concentration (B). Only a slight increase in the maximum removal efficiency of Se(VI) was observed (> 60\% and $90 \%$ at 100 ppm and 10 ppm initial Se concentration, respectively) in MSA 613 and MSA 514 samples. This increase in the removal efficiency of Se(VI) during coprecipitation experiments may suggests that Se(VI) could be incorporated within the mineral structure of Mg-bearing minerals in addition to surface adsorption. Also, no significant effect of temperature was observed in the removal of Se(VI) during coprecipitation experiments.

\subsection{Stability test of selenate using phosphate anion extractant}

The stability test of Se(VI) using phosphate as extractant anion was conducted for MSA 613, MSA 514 and MSA 415 samples in order to determine whether Se(VI) can be irreversibly fixed by Mgbearing minerals. Figure 8 shows the desorption efficiency of adsorbed (A) and coprecipitated (B) Se(VI). The results revealed that more than $80 \%$ of the adsorbed and coprecipitated Se(VI) was removed in $0.1 \mathrm{M} \mathrm{Na}_{2} \mathrm{HPO}_{4}$ solution. Regardless of temperature, the irreversible fraction of sorbed Se(VI) (about 10\%) was observed only in serpentine-like minerals (MSA 514 samples). In MSA 613 samples, about $20 \%$ of irreversibly fixed $\mathrm{Se}(\mathrm{VI})$ was observed only at $75^{\circ} \mathrm{C}$. At lower Se concentration however, only hydrotalcite phases (MSA 712 and MSA 613) showed significant irreversibly bound fraction of Se(VI) (data not shown). 
Based from the XANES data (Figure 9), the absorption edges of Se retained by hydrotalcite and serpentine-like phases were all identical and matched the Se(VI) standard located at $12665 \mathrm{eV}$. This clearly shows that no shifts in its oxidation state occurred during the adsorption snd coprecipitation reactions with Mg-bearing minerals. Similar results were also observed by ${ }^{77}$ Se NMR data of selenooxyanions in hydrotalcite-like compounds (Hou and Kirkpatrick, 2000). The coordination number $(\mathrm{CN})$, inter-atomic distance $(\mathrm{R})$, and Debye-Waller factor $\left(\sigma^{2}\right)$ based from the fitted structural parameters for selenium is shown in Table 3. The single Se-O shell with CN of 4 at 1.64 to $1.65 \AA$ was adequately fitted from the experimental data of the analyzed samples. This bond distance is consistent with previously published data on Se-O distances (Hou and Kirkpatrick, 2000; Peak, 2006). However, a second shell Se-Al/Mg distance was not detected.

\subsection{Selenate retention mechanisms}

Based on the XAFS data, the absence of second shell Se-Al/Mg distance suggests that $\mathrm{Se}(\mathrm{VI})$ was mainly retained via outer-sphere complexation as suggested by previous studies. The high desorption efficiency of adsorbed and coprecipitated Se(VI) in phosphate bearing solution also suggests that it was mainly adsorbed on the mineral surface and in the disordered interlayers of hydrotalcite (Hou and Kirkpatrick, 2000) and serpentine-like minerals. The observed increase in the basal spacing of Opiso et al., 2010; Goldberg, 2013). hydrotalcite also indicates the retention of Se(VI) in the interlayer (You et al., 2001). However, the formation of inner-sphere complexes and incorporation within the mineral structure cannot be ruled out completely for serpentine-like minerals due to the observed irreversibly bound fraction of Se(VI). The formation of both outer-sphere and inner-sphere complexes and replacement of Si by arsenate in the tetrahedral sheet of serpentine was already reported in several studies (Charnock et al., 2007;

\section{Conclusions}


The results of this study have several important implications in the possible application of hydrotalcite and aluminian serpentine in Se(VI) immobilization. First, hydrotalcite and serpentine-like mineral phases with $\mathrm{Mg} / \mathrm{Al}$ ratio of 2 and 1.25, respectively, can directly remove Se(VI) from contaminated water and wastewater at alkaline condition. Second, the difference in the removal efficiency of Se(VI) between adsorption (> 50 and $80 \%$ at initial Se concentration of 100 and $10 \mathrm{ppm}$, respectively) and coprecipitation experiments (> 60 and $90 \%$ at initial Se concentration of 100 and 10 ppm, respectively) was not significant. So, the use of Mg-bearing minerals in Se(VI) immobilization can be applied in various countermeasure where adsorption and/or coprecipitation techniques is necessary. Third, higher temperature of $75^{\circ} \mathrm{C}$ could enhance the formation of Mg-bearing minerals but the effect of temperature in Se(VI) immobilization was also minimal. This could suggests that the treatment of Se(VI) via adsorption and coprecipitation reactions with Mg-bearing minerals requires less energy input. Fourth, more than $80 \%$ of sorbed Se(VI) was released after desorption experiments which could be attributed to its outer-sphere complexation onto Mg-bearing minerals. Thus, regenerating these Mg-bearing minerals as adsorbent in several cycles should be possible.

\section{Acknowledgement}

The authors would like to thank the Nuclear Safety Research Association of Japan for providing the necessary financial support in the conduct of this study. Thanks are also due to the Photon Factory Program Advisory Committee, KEK, Tsukuba, Japan for providing the operating time in conducting the XAFS analysis of our samples (Proposal No. 2008G577). Thanks are also due to Dr. Kazuya Morimoto, Mr. Sohtaro Anraku and Dr. John Charnock for their assistance in the conduct and data analysis for EXAFS and XANES as well as to Dr. Carlito Tabelin for his assistance and helpful discussion concerning selenate leaching behavior.

\section{References}

Albertazzi, S., Basile, F., Benito, P., Del Gallo, P., Fornasari, G., Gary, D., Rosetti, V., and Vaccari, A., 2007. Effect of silicates on the structure of Ni-containing catalysts obtained from hydrotalcite-type 
precursors. Catal. Today.128, 258-263.

Anraku, S., Morimoto, K., Sato, T., and Yoneda, T., 2008. Natural Analogue Study on Mineral Formation and Anion Uptake at the Hyperalkaline Conditions. Geochim. Cosmochim. Ac. 72, Supplement 28.

Baskaran, T., Kumaravel, R., Christopher, J., and Sakthivel, A., 2013. Silicate anion-stabilized layered magnesium-aluminium hydrotalcite. RSC Adv. 3, 16392-16398.

Charnock, J., Polya, D., Gault A., Wogelius, R., 2007. Direct EXAFS evidence for incorporation of As5+ in the tetrahedral site of natural andraditic garnet. Am. Mineral. 92, 1856-1861.

Chugh, Y., Behum, P., 2014. Coal waste management practices in the USA: an overview. Int J Coal Sci Technol. 1(2):163-176.

Cornelis, G., Johnson, C.A., Gerven, T.V. and Vandecasteele, C., 2008. Leaching mechanisms of oxyanionic metalloid and metal species in alkaline solid wastes: A review. Appl. Geochem. 23, 955976.

Craw, D., Landis, C. A., Kelsey, P. I., 1987. Authigenic Chrysotile Formation in the Matrix of our Ternary Debris Flows, Northern Southland, New Zealand. Clay Clay Miner., 35, 43-52.

Das, S., Jim Hendry, M., Essilfie-Dughan, J., 2013. Adsorption of selenate onto ferrihydrite, goethite, and lepidocrocite under neutral pH conditions. Appl. Geochem. 28, 185-193.

De la Calle, C., Pons, C., Roux, J., Rives, V., 2003. A crystal-chemical study of natural and synthetic anionic clays. Clay Clay Miner. 51, 121-132.

Depege, C., El Metoui, F., Forano, C., de Roy, A., Dupuis, J., Besse J., 1996. Polymerization of 
silicates in layered double hydroxides. Chem. Mater. 8, 952-960.

Goldberg, S. 2012. Modeling Selenite Adsorption Envelopes on Oxides, Clay Minerals, and Soils using the Triple Layer Model. Soil Sci. Soc. Am. J. 77:64-71.

Goldberg, S. 2013. Macroscopic Experimental and Modeling Evaluation of Selenite and Selenate Adsorption Mechanisms on Gibbsite. Soil Sci. Soc. Am. J. 78:473-479.

Gonzalez, C.M., Hernandez, J., Parsons, J.G., Gardea-Torresdey, J.L., 2010. A study of the removal of selenite and selenate from aqueous solutions using a magnetic iron/manganese oxide nanomaterial and ICP-MS. Microchem. J. 96, 324-329.

Hou, X., Kirkpatrick, R., 2000. Solid-state ${ }^{77}$ Se NMR and XRD study of the structure and dynamics of seleno-oxyanions in hydrotalcite-like compounds. Chem Mater. 12(7):1890-1897.

Liu, X., Sato, T., Opiso, E., Yoneda, T. 2012. Adsorption and co-precipitation behavior of fluoride onto Mg-bearing minerals in Si-Al-Mg mineral system at hyperalkaline conditions. Clay Science, 16, 49-57.

Masscheleyn, P., Delaune, R., Patrick, W., 1990. Transformations of selenium as affected by sediment oxidation-reduction potential and pH. Environ. Sci. Technol. 24:91-96.

Mizutani, T., Fukushima Y. and Kamigaito O., 1990. Synthesis of Nickel and Magnesium phyllosilicates with 1:1 and 2:1 layer structures. Bull. Chem. Soc. Jpn. 63 (7), 2091-2098.

Moroz, T., Razvorotneva, L., Grigorieva, T., Mazurov, M., Arkhipenko, D., Prugov, V., 2001. Formation of spinel from hydrotalcite-like minerals and destruction of chromite implanted by inorganic salts. Appl. Clay Sci. 18, 29-36. 
Opiso, E., Sato, T., Morimoto, K., Asai, A., Anraku, S., Numako, C., Yoneda, T., 2010. Incorporation of arsenic during the formation of Mg-bearing minerals at alkaline condition. Miner. Eng. 23, 230-237.

Opiso, E., Asai, A., Sato, T., Yoneda, T. and Liu, X. 2012. Sorption Behavior of Arsenate by Mg-

Bearing Minerals at Hyperalkaline Condition: Implications for oxyanions sequestration during the use and disposal of alkaline wastes. Water Air Soil Poll. 223, 3471-3483.

Peak, D., 2006. Adsorption mechanisms of selenium oxyanions at the aluminum oxide/water interface.

J. Colloid Interf. Sci. 303, 337-345.

385 Environ. 521-522, 246-260. 42, 283-294. Food Chem. 134, 1932-1937.

397 473, 244-253.

401

Sigrist, M., Brusa, L., Campagnoli, D., Beldomenico, H., 2012. Determination of seleniumin selected food samples from Argentina and estimation of their contribution to the Se dietary intake.

Tabelin, C., Hashimoto, A., Igarashi, T. Yoneda, T., 2014. Leaching of boron, arsenic and selenium from sedimentary rocks: II. pH dependence, speciation and mechanisms of release. Sci. Total Environ.

Tamoto, S., Tabelin, C., Igarashi, T., Ito, M., Hiroyoshi, N. 2015. Short and long term release 
403

404

405

406

407

408

409

410

411

412

413

414 Van der Hoek, E.E., Bonouvrie, P.A. and Comans, R.N.J., 1994. Sorption of As and Se on mineral 415

416

417

418

419

mechanisms of arsenic, selenium and boron from a tunnel-excavated sedimentary rock under in situ conditions. J Contam Hydrol. 175, 60-71.

Taylor, J.B., Reynolds, L.P., Redmer, D.A., Caton, J.S., 2009. Maternal and fetal tissue selenium loads in nulliparous ewes fed supranutritional and excessive selenium during mid- to late pregnancy. J. Anim. Sci. 87, 1828-1834.

USEPA, 2014. External Peer Review Draft - Aquatic Life Ambient Water Quality Criterion for Selenium - Freshwater 2014, EPA-820-F-14-005 2014. United States Environmental Protection Agency, Washington, DC. components of fly ash: relevance for leaching process. Appl. Geochem. 9, 403-412.

You, Y., Vance, G. and Zhao, H., 2001. Selenium adsorption on Mg-Al and Zn-Al layered double hydroxides. Appl. Clay Sci. 20, 13-25. 
Table 1. Mg/Si/Al molar ratio, solid mineralogy and amount of adsorbed selenate by Mg-bearing minerals

\begin{tabular}{|c|c|c|c|c|c|c|c|c|c|}
\hline \multirow{3}{*}{$\begin{array}{l}\text { Sample } \\
\text { Name }\end{array}$} & \multicolumn{3}{|c|}{ Mg/Al Ratio } & \multicolumn{6}{|c|}{ Temperature $\left({ }^{\circ} \mathrm{C}\right)$} \\
\hline & $\mathrm{Mg}$ & $\mathrm{Si}$ & $\mathrm{Al}$ & \multicolumn{2}{|c|}{25} & \multicolumn{2}{|c|}{50} & \multicolumn{2}{|c|}{75} \\
\hline & & & & $\begin{array}{c}\text { Dominant } \\
\text { Mineral }\end{array}$ & $\begin{array}{c}\text { Sorbed Amount } \\
\text { (mmol Se/g solids) }\end{array}$ & $\begin{array}{c}\text { Dominant } \\
\text { Mineral }\end{array}$ & $\begin{array}{l}\text { Sorbed Amount } \\
\text { (mmol Se/g solids) }\end{array}$ & $\begin{array}{c}\text { Dominant } \\
\text { Mineral }\end{array}$ & $\begin{array}{c}\text { Sorbed Amount } \\
\text { (mmol Se/g solids) }\end{array}$ \\
\hline MSA 811 & 8 & 1 & 1 & Hydrotalcite & 0.03 & Hydrotalcite & 0.02 & Hydrotalcite & 0.02 \\
\hline MSA 712 & 7 & 1 & 2 & Hydrotalcite & 0.25 & Hydrotalcite & 0.19 & Hydrotalcite & 0.14 \\
\hline MSA 613 & 6 & 1 & 3 & Hydrotalcite & 0.41 & Hydrotalcite & 0.42 & Hydrotalcite & 0.39 \\
\hline MSA 514 & 5 & 1 & 4 & $\begin{array}{l}\text { Hydrotalcite \& } \\
\text { Serpentine }\end{array}$ & 0.40 & Serpentine & 0.35 & Serpentine & 0.30 \\
\hline MSA 415 & 4 & 1 & 5 & Serpentine & 0.22 & Serpentine & 0.24 & Serpentine & 0.19 \\
\hline MSA 316 & 3 & 1 & 6 & Serpentine & 0.05 & Serpentine & 0.04 & Serpentine & 0.05 \\
\hline
\end{tabular}

Table 2. Mg/Si/Al molar ratio, solid mineralogy and amount of coprecipitated selenate by Mg-bearing minerals

\begin{tabular}{|c|c|c|c|c|c|c|c|c|c|}
\hline \multirow{3}{*}{$\begin{array}{l}\text { Sample } \\
\text { Name }\end{array}$} & \multicolumn{3}{|c|}{ Mg/Al Ratio } & \multicolumn{6}{|c|}{ Temperature $\left({ }^{\circ} \mathrm{C}\right)$} \\
\hline & $\mathrm{Mg}$ & $\mathrm{Si}$ & $\mathrm{Al}$ & \multicolumn{2}{|c|}{25} & \multicolumn{2}{|c|}{50} & \multicolumn{2}{|c|}{75} \\
\hline & & & & $\begin{array}{l}\text { Dominant } \\
\text { Mineral }\end{array}$ & $\begin{array}{l}\text { Sorbed Amount } \\
\text { (mmol Se/g solids) }\end{array}$ & $\begin{array}{c}\text { Dominant } \\
\text { Mineral }\end{array}$ & $\begin{array}{l}\text { Sorbed Amount } \\
\text { (mmol Se/g solids) }\end{array}$ & $\begin{array}{c}\text { Dominant } \\
\text { Mineral }\end{array}$ & $\begin{array}{l}\text { Sorbed Amount } \\
\text { (mmol Se/g solids) }\end{array}$ \\
\hline MSA 811 & 8 & 1 & 1 & Hydrotalcite & 0.04 & Hydrotalcite & 0.07 & Hydrotalcite & 0.04 \\
\hline MSA 712 & 7 & 1 & 2 & Hydrotalcite & 0.20 & Hydrotalcite & 0.18 & Hydrotalcite & 0.19 \\
\hline MSA 613 & 6 & 1 & 3 & Hydrotalcite & 0.31 & Hydrotalcite & 0.40 & Hydrotalcite & 0.46 \\
\hline MSA 514 & 5 & 1 & 4 & $\begin{array}{l}\text { Hydrotalcite \& } \\
\text { Serpentine }\end{array}$ & 0.46 & Serpentine & 0.42 & Serpentine & 0.46 \\
\hline MSA 415 & 4 & 1 & 5 & Serpentine & 0.32 & Serpentine & 0.21 & Serpentine & 0.23 \\
\hline MSA 316 & 3 & 1 & 6 & Serpentine & 0.09 & Serpentine & 0.06 & Serpentine & 0.10 \\
\hline
\end{tabular}


Table 3 Fitted structural parameters derived from Se K-edge EXAFS of coprecipitated $\mathrm{Se}^{6+}$ with Mg-bearing minerals

\begin{tabular}{|c|c|c|c|c|c|}
\hline \multirow[t]{3}{*}{ Sample } & \multirow[t]{3}{*}{ Temperature } & \multirow[t]{3}{*}{ Dominant mineralogy } & \multicolumn{3}{|c|}{ First-shell } \\
\hline & & & \multicolumn{3}{|c|}{ Se-O } \\
\hline & & & $\mathrm{CN}$ & $r(\AA)$ & $\sigma^{2}$ \\
\hline MSA 613 & \multirow{3}{*}{$25^{\circ} \mathrm{C}$} & Hydrotalcite & 3.5 & 1.64 & 0.002 \\
\hline MSA 514 & & Hydrotalcite \& Serpentine & 3.7 & 1.65 & 0.002 \\
\hline MSA 415 & & Serpentine & 3.6 & 1.66 & 0.004 \\
\hline MSA 613 & \multirow{3}{*}{$50^{\circ} \mathrm{C}$} & Hydrotalcite & 3.9 & 1.63 & 0.002 \\
\hline MSA 514 & & Serpentine & 3.7 & 1.64 & 0.002 \\
\hline MSA 415 & & Serpentine & 3.2 & 1.66 & 0.007 \\
\hline MSA 613 & \multirow{3}{*}{$75^{\circ} \mathrm{C}$} & Hydrotalcite & 3.6 & 1.64 & 0.002 \\
\hline MSA 514 & & Serpentine & 3.3 & 1.65 & 0.002 \\
\hline MSA 415 & & Serpentine & 3.5 & 1.65 & 0.002 \\
\hline
\end{tabular}

Note: No second shell coordination of analyzed samples were detected 
A

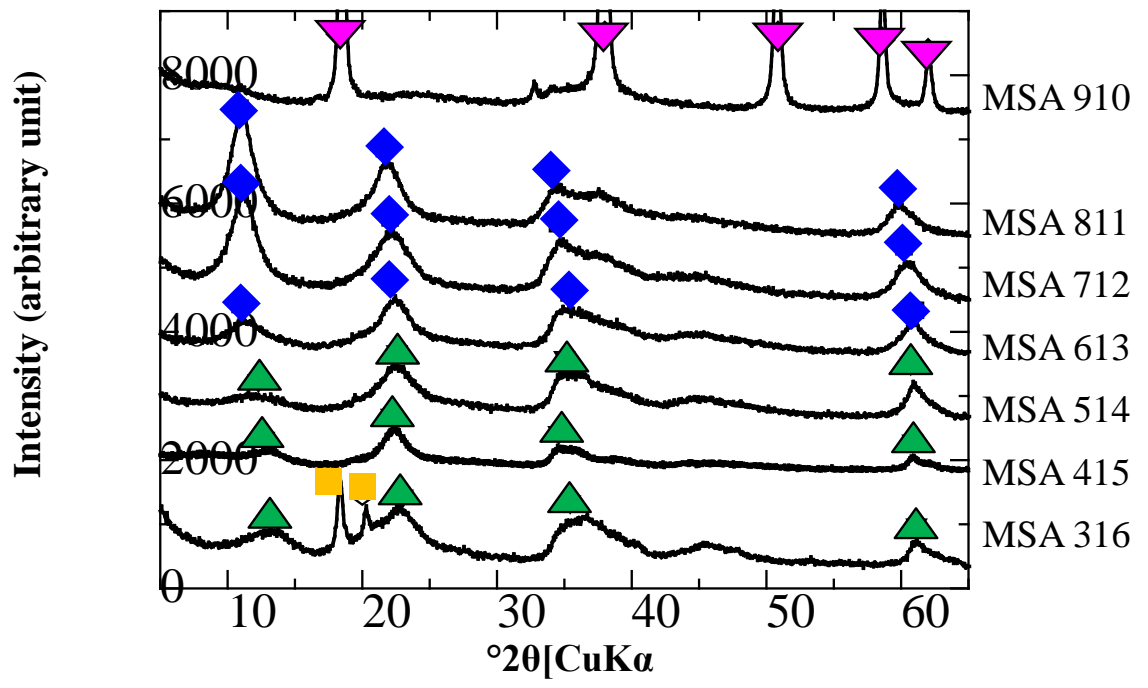

B

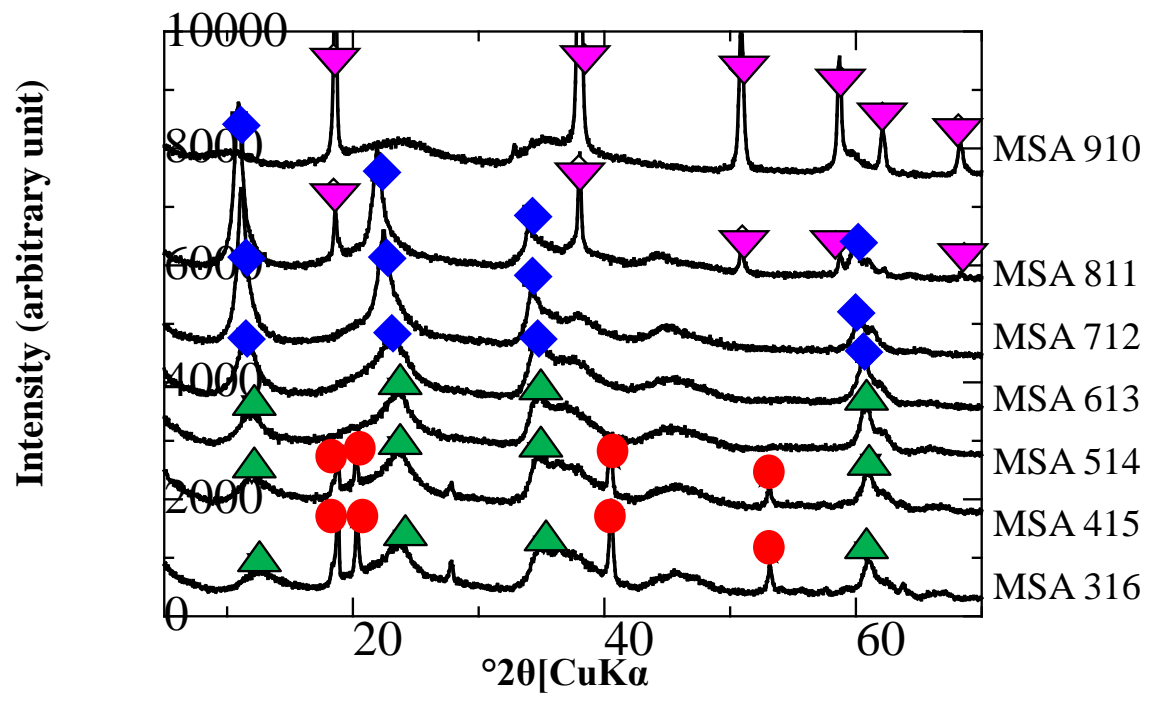

Figure $1 \mathrm{XRD}$ patterns of pure synthesized Mg-bearing minerals at $25^{\circ} \mathrm{C}$ and $75^{\circ} \mathrm{C}$. brucite

hydrotalcite $\triangle$ serpentine gibbsite bayerite 


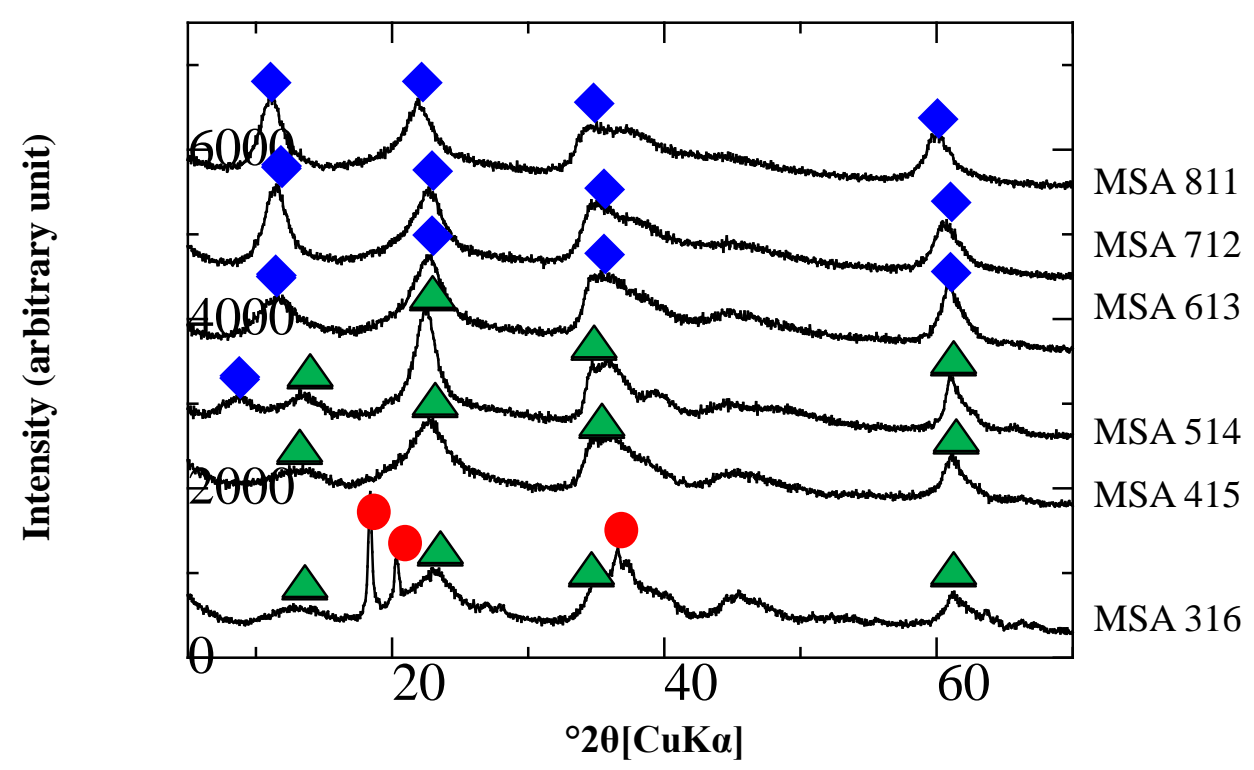

B

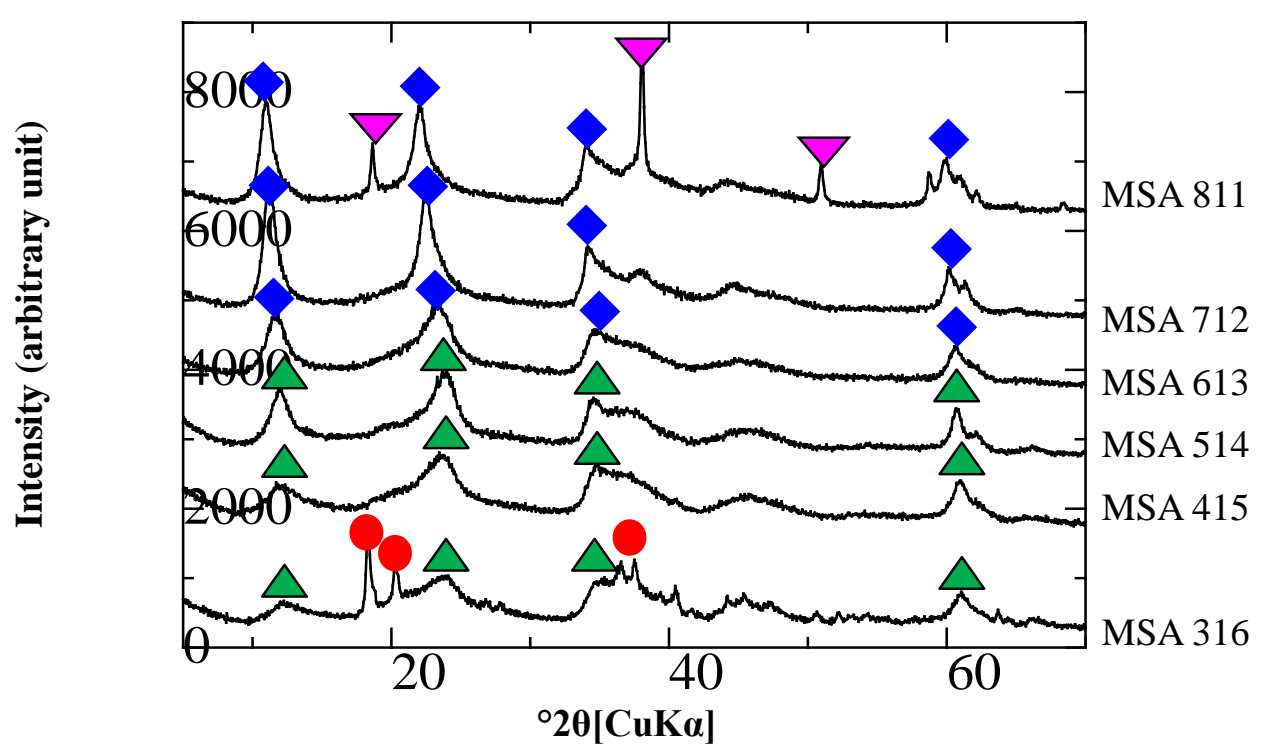

Figure 2 XRD patterns of the synthesized phases after selenate adsorption using $100 \mathrm{ppm}$ initial selenium concentration.

Note: A: $\mathbf{T}=25^{\circ} \mathrm{C}$; $\mathrm{B}: \mathbf{T}=75^{\circ} \mathrm{C}$

$\nabla$ brucite $\diamond$ hydrotalcite $\triangle$ serpentine $\bigcirc$ gibbsite 


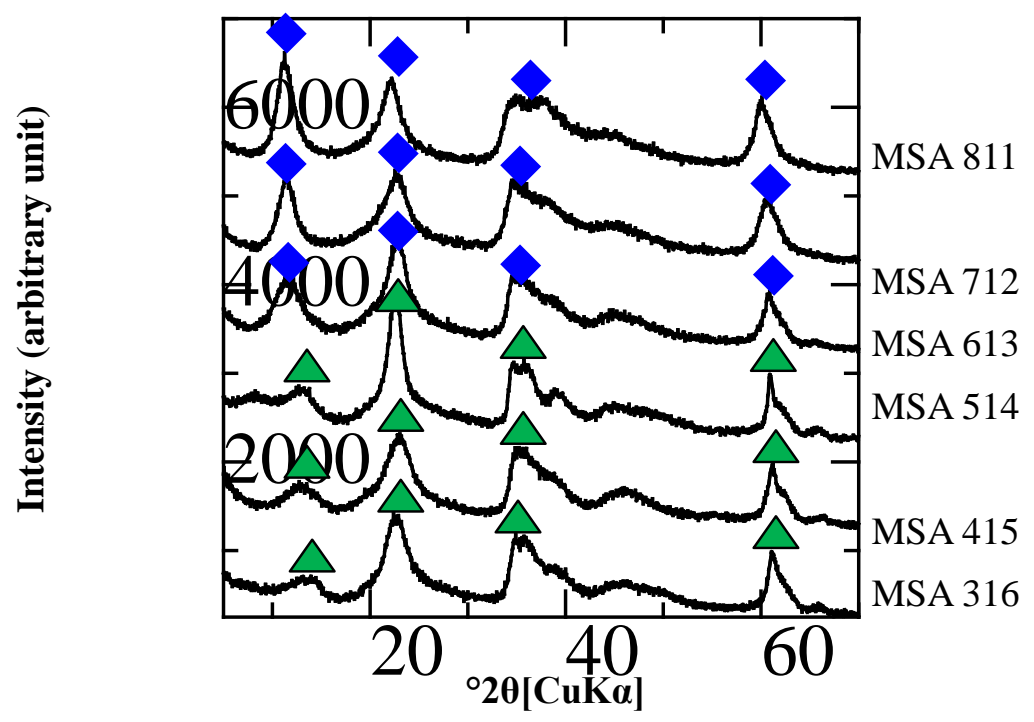

Figure 3 XRD patterns of synthesized phases after selenate adsorption using $10 \mathrm{ppm}$ initial selenium concentration at $25^{\circ} \mathrm{C}$

Note: $\diamond$ hydrotalcite $\triangle$ serpentine 
A

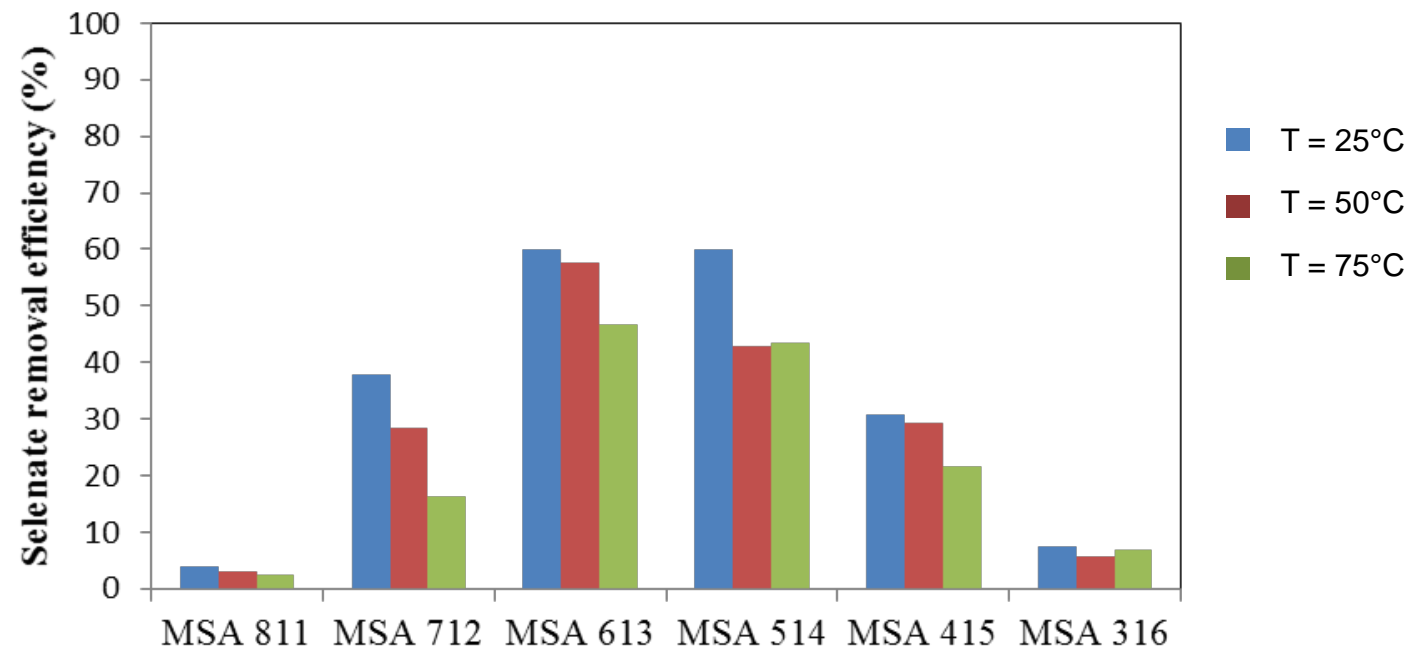

Sample name

B

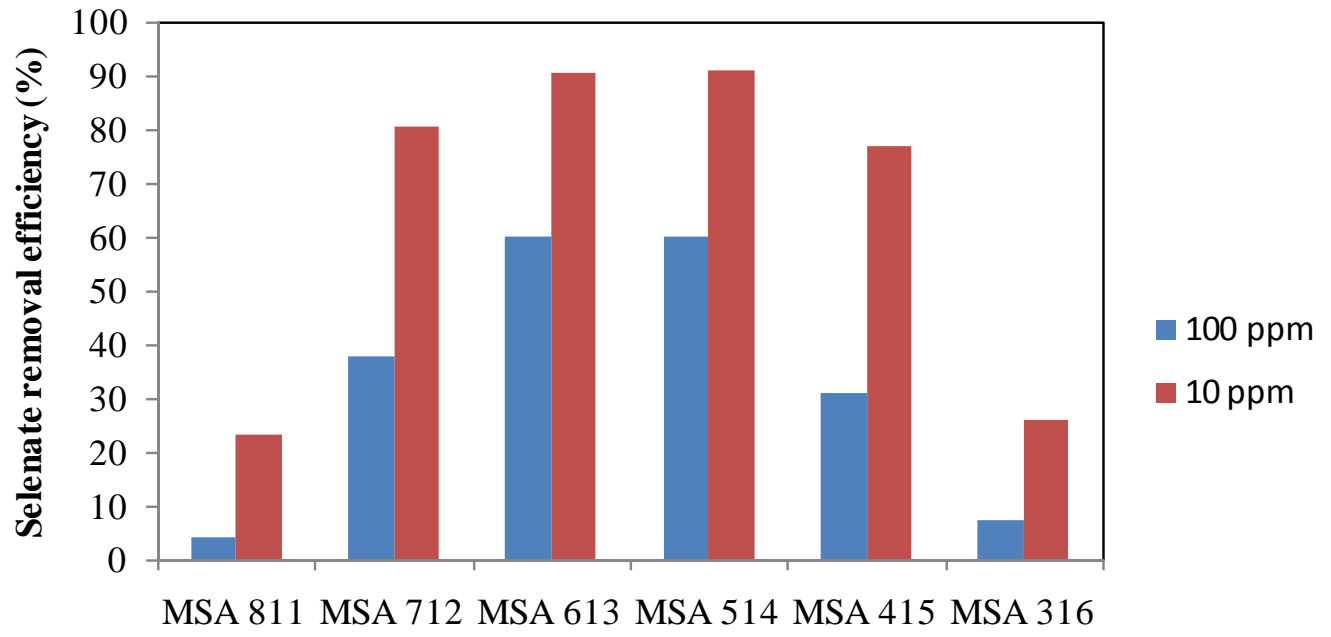

Sample name

Figure 4 Comparison between the removal efficiency of adsorbed selenium by the generated phases at different temperature conditions (A) and initial Se concentration (B). 


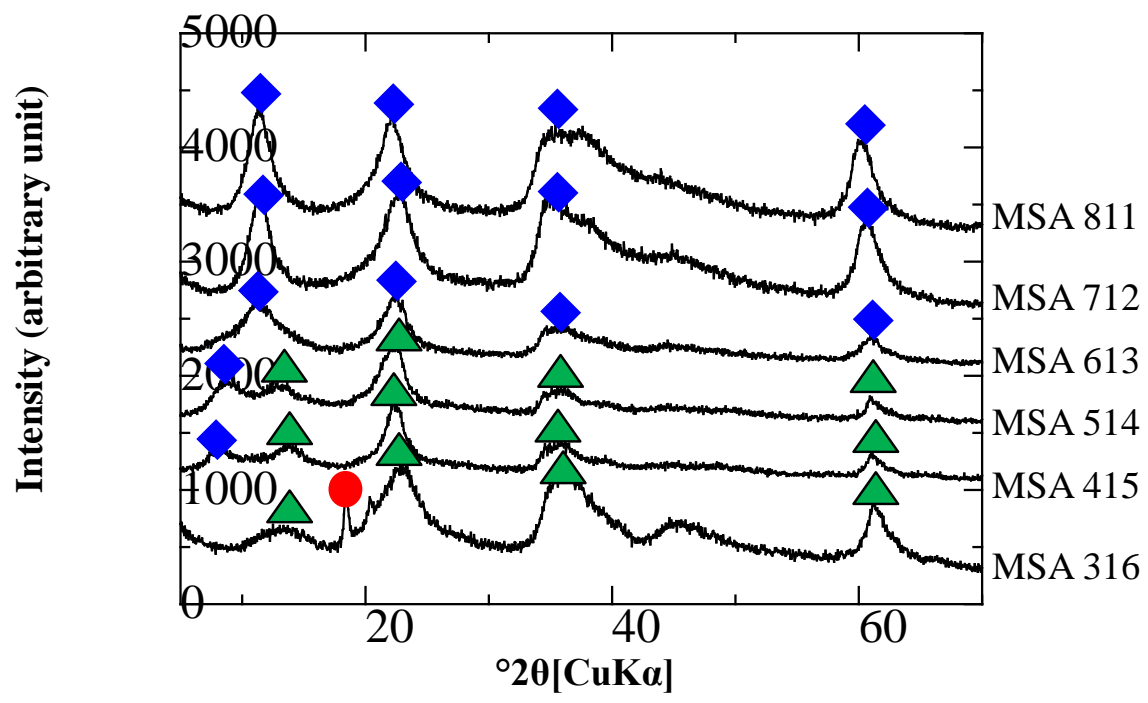

B

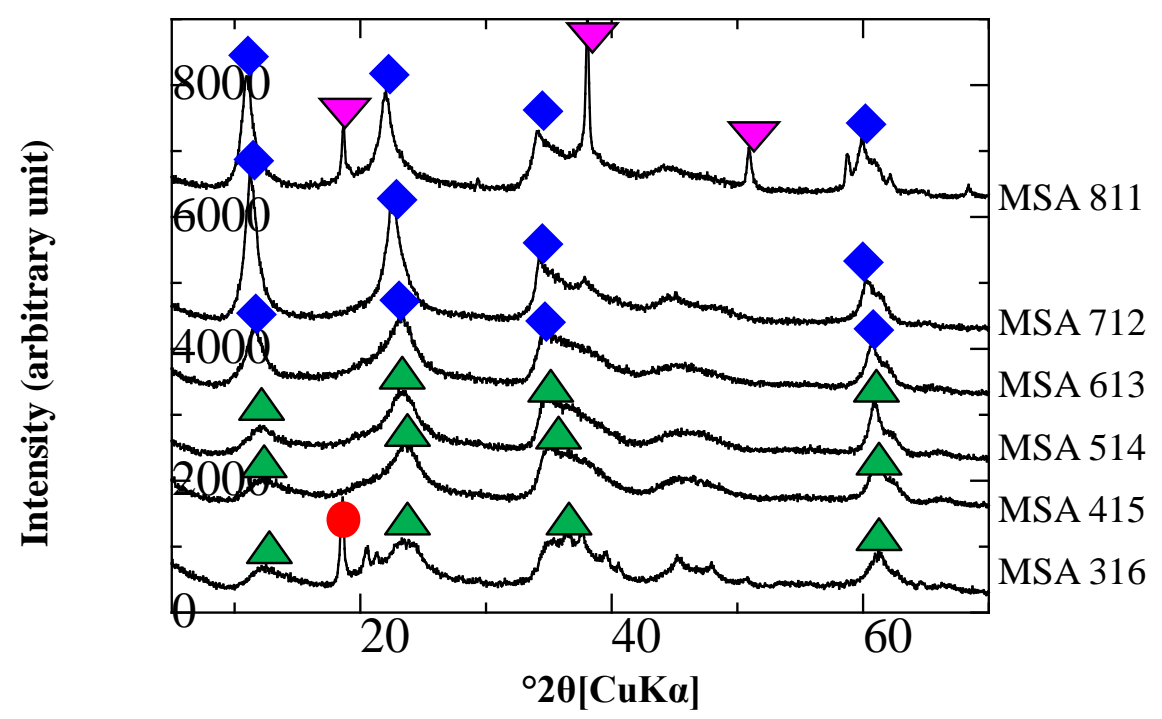

Figure 5 XRD patterns of the synthesized phases after selenate coprecipitation. Note: $A: T=25^{\circ} \mathrm{C} ; \mathrm{B}: \mathrm{T}=75^{\circ} \mathrm{C}$

$\nabla$ brucite hydrotalcite $\triangle$ serpentine gibbsite 


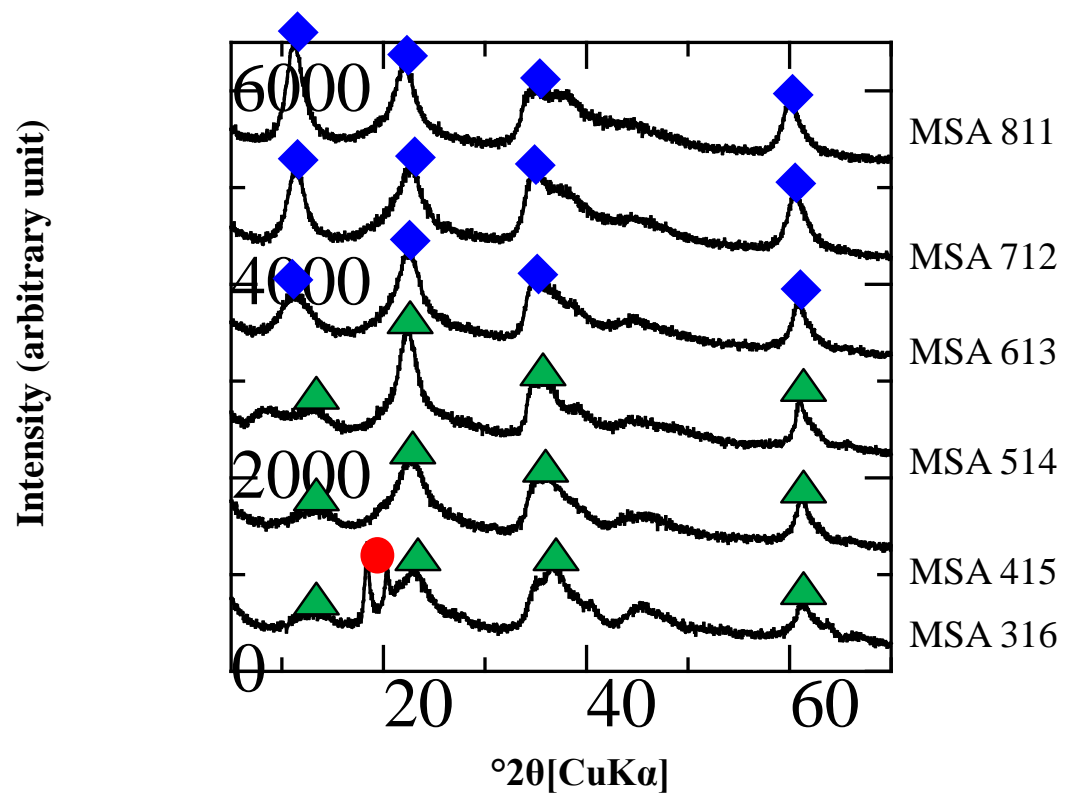

Figure 6 XRD patterns of synthesized phases after selenate coprecipitation using $10 \mathrm{ppm}$ initial selenium concentration at $25^{\circ} \mathrm{C}$

Note: $\diamond$ hydrotalcite $\triangle$ serpentine $\bigcirc$ gibbsite 
A

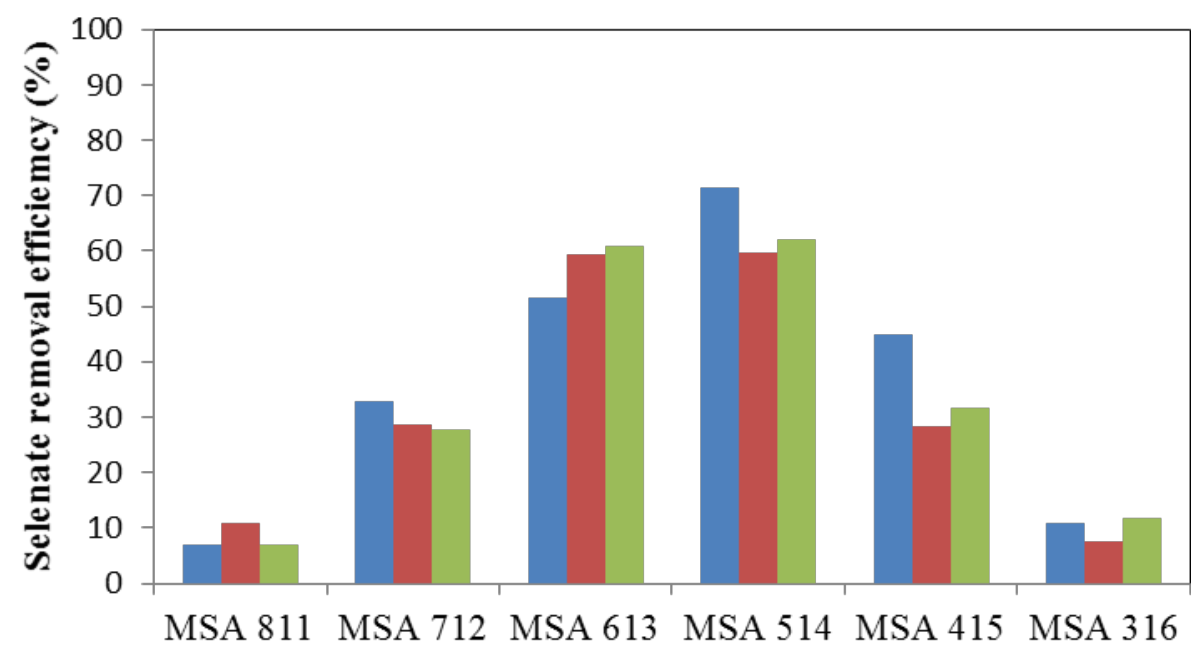

$\mathrm{T}=25^{\circ} \mathrm{C}$

- $\mathrm{T}=50^{\circ} \mathrm{C}$

$\mathrm{T}=75^{\circ} \mathrm{C}$

Sample name

B

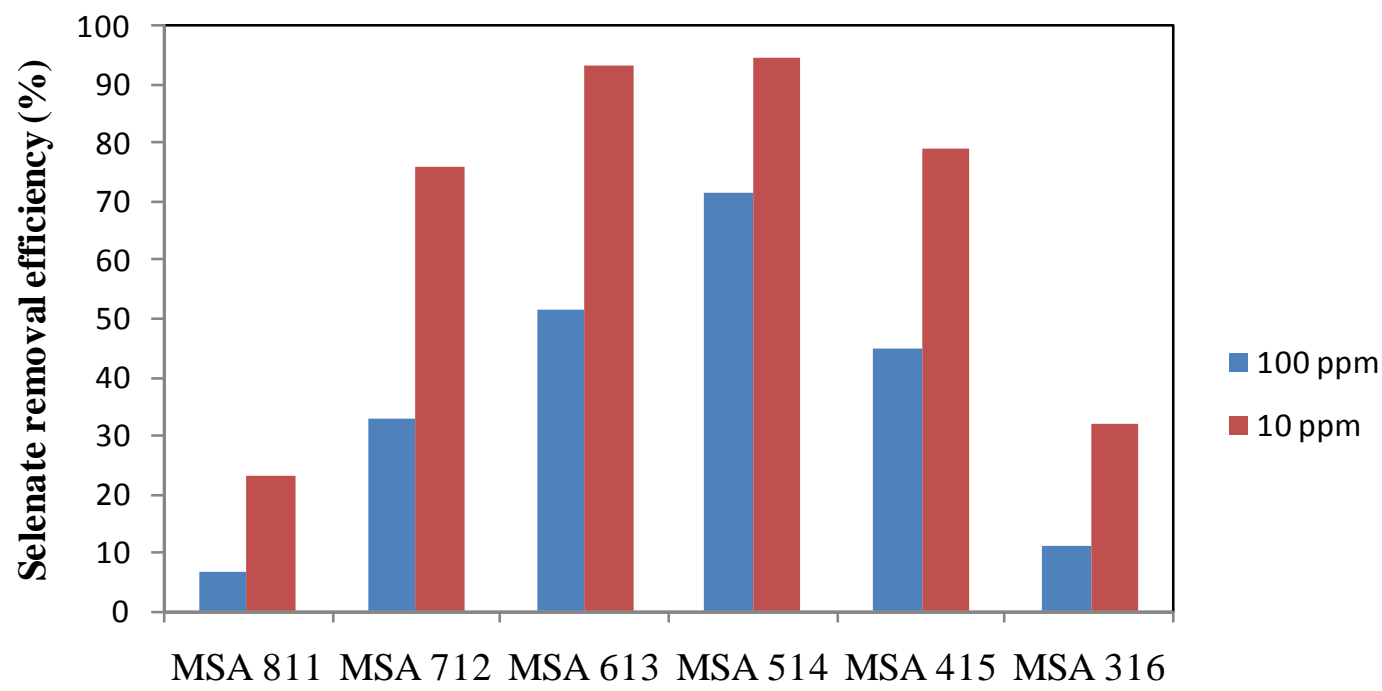

Sample name

Figure 7 Comparison between the removal efficiency of co-precipitated selenate by the generated phases at different temperature conditions (A) and initial Se concentration (B). 
A

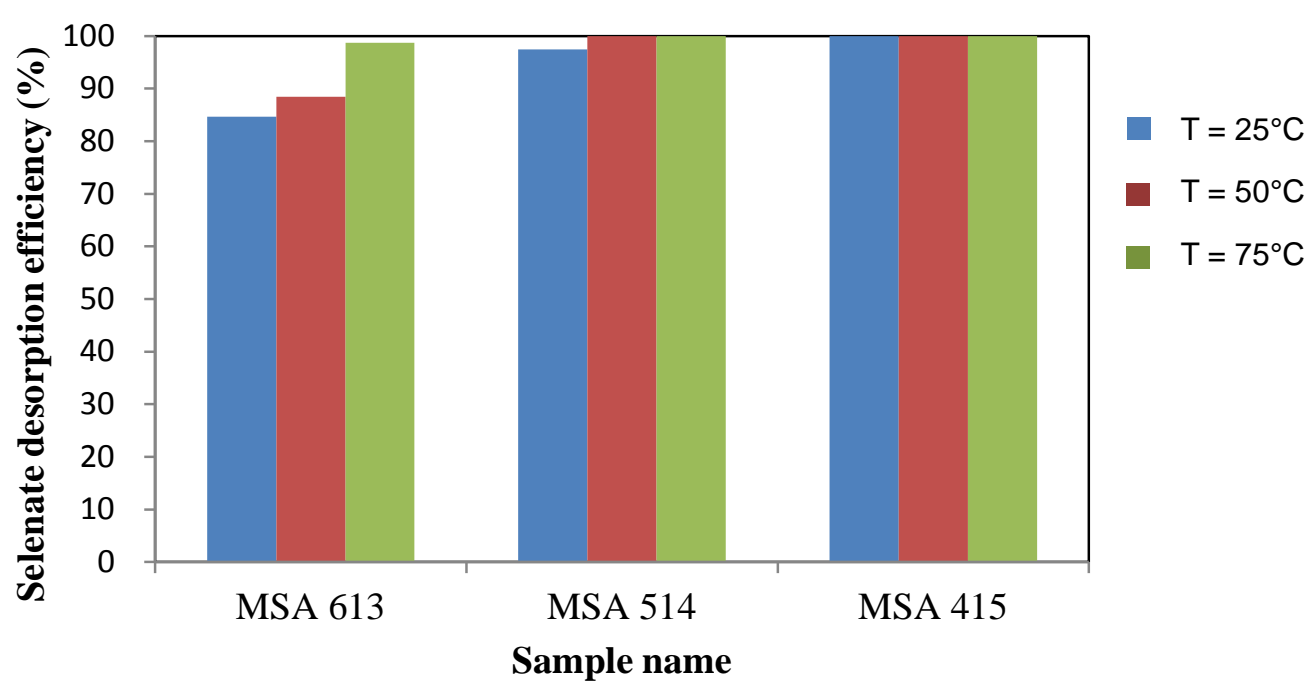

B

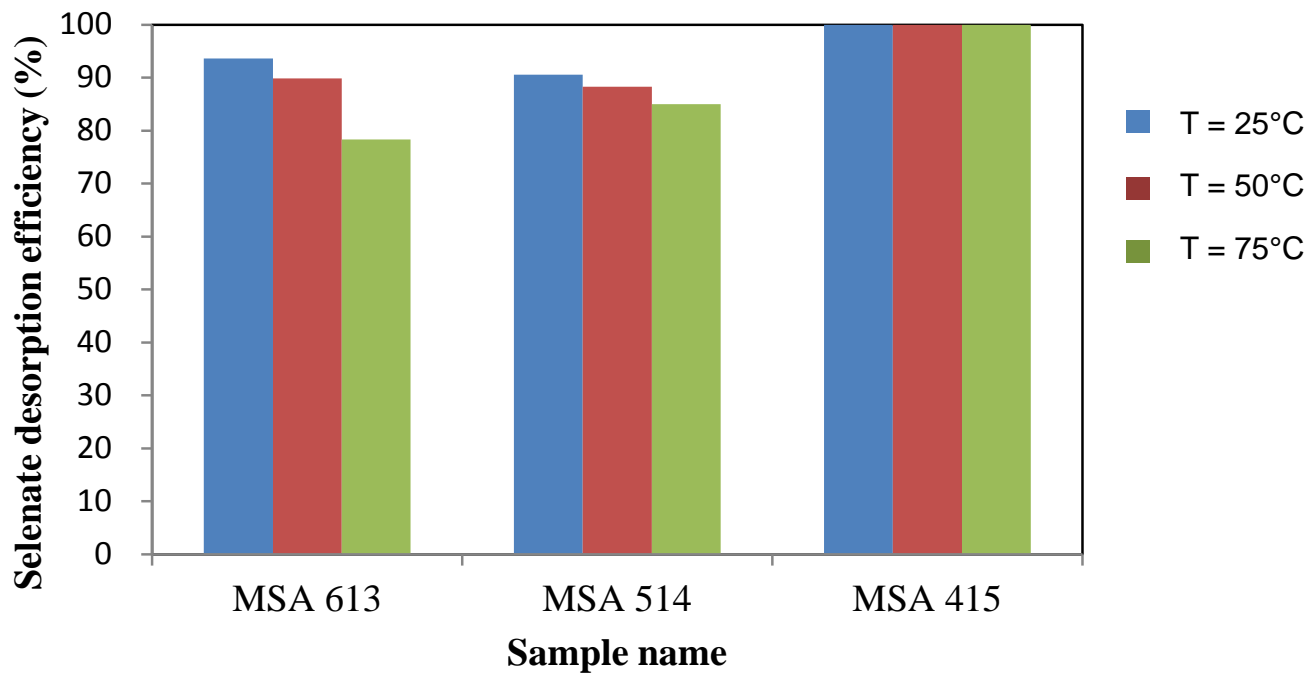

Figure 8 Selenate desorption efficiency after adsorption (A) and coprecipitation (B) experiments. 


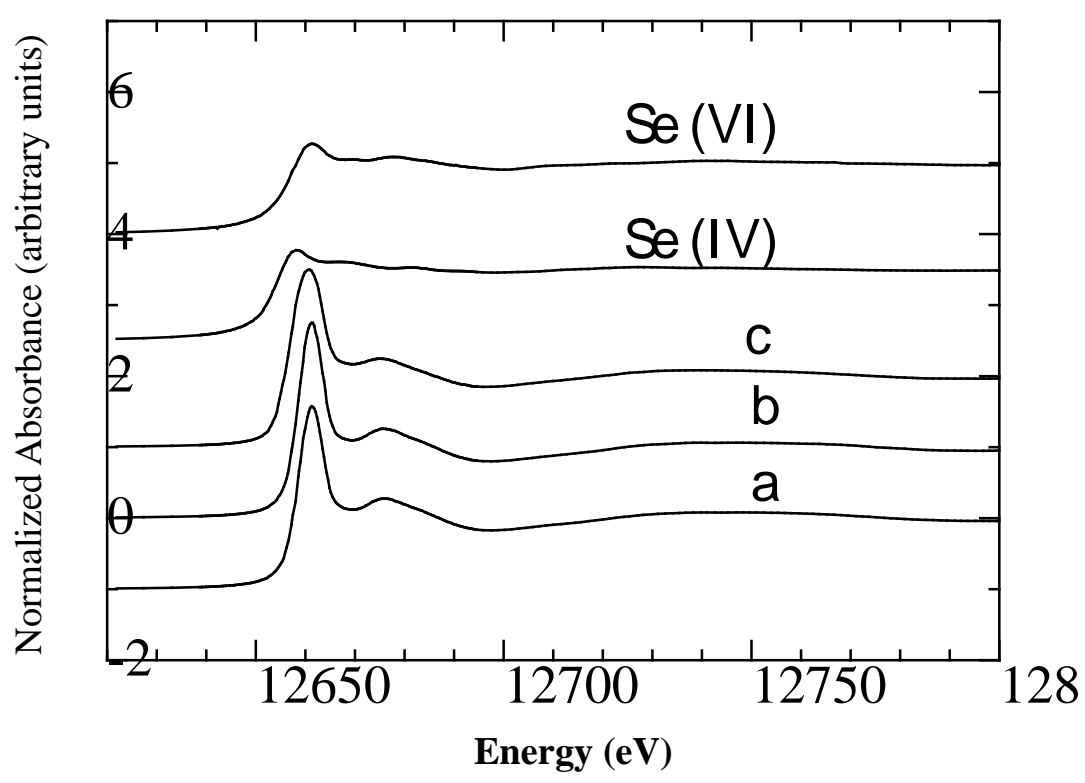

Figure 9 Se K-edge XANES spectra of selenium sorbed on hydrotalcite and serpentine phases formed at $50^{\circ} \mathrm{C}$. Note: MSA 415(a) to MSA 613 (c)

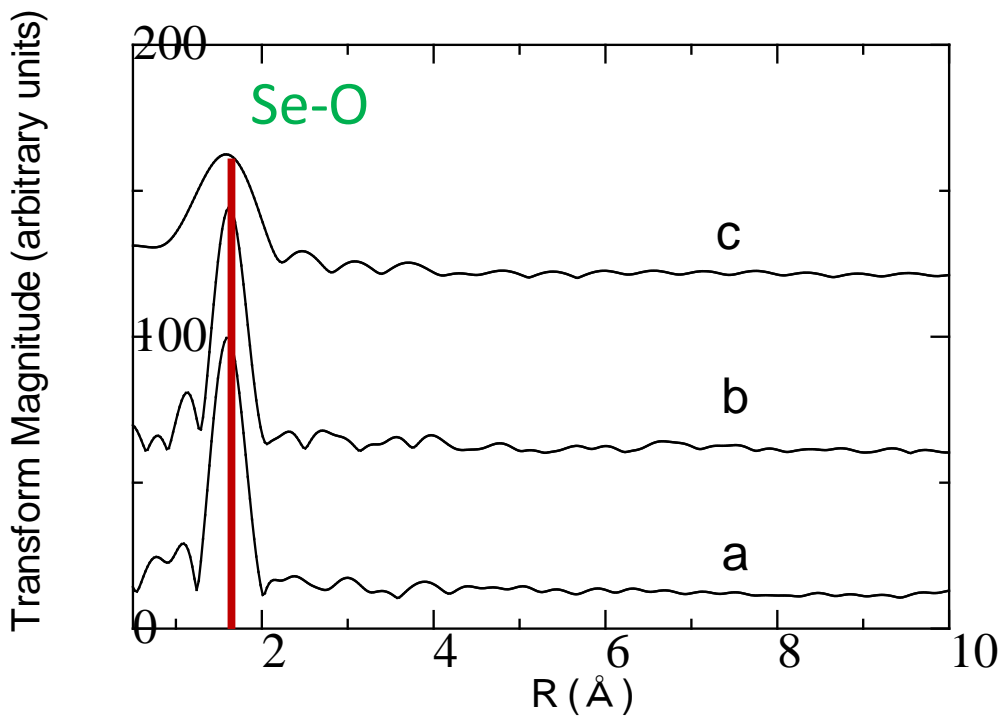

Figure 10 RDF profile with peak positions derived from the Se K-edge EXAFS of selected samples with coprecipitated selenate formed at $50^{\circ} \mathrm{C}$

Note: MSA 415 (a) to MSA 613 (c) 